\title{
EFFECT OF ANTIBROWNING AGENTS ON COLOR AND RELATED ENZYMES IN FRESH-CUT APPLES DURING COLD STORAGE
}

\section{This is the author's manuscript}

Original Citation:

Availability:

This version is available http://hdl.handle.net/2318/100497

since 2016-02-03T15:05:56Z

Published version:

DOI:10.1111/j.1745-4549.2011.00561.x

Terms of use:

Open Access

Anyone can freely access the full text of works made available as "Open Access". Works made available under a Creative Commons license can be used according to the terms and conditions of said license. Use of all other works requires consent of the right holder (author or publisher) if not exempted from copyright protection by the applicable law. 


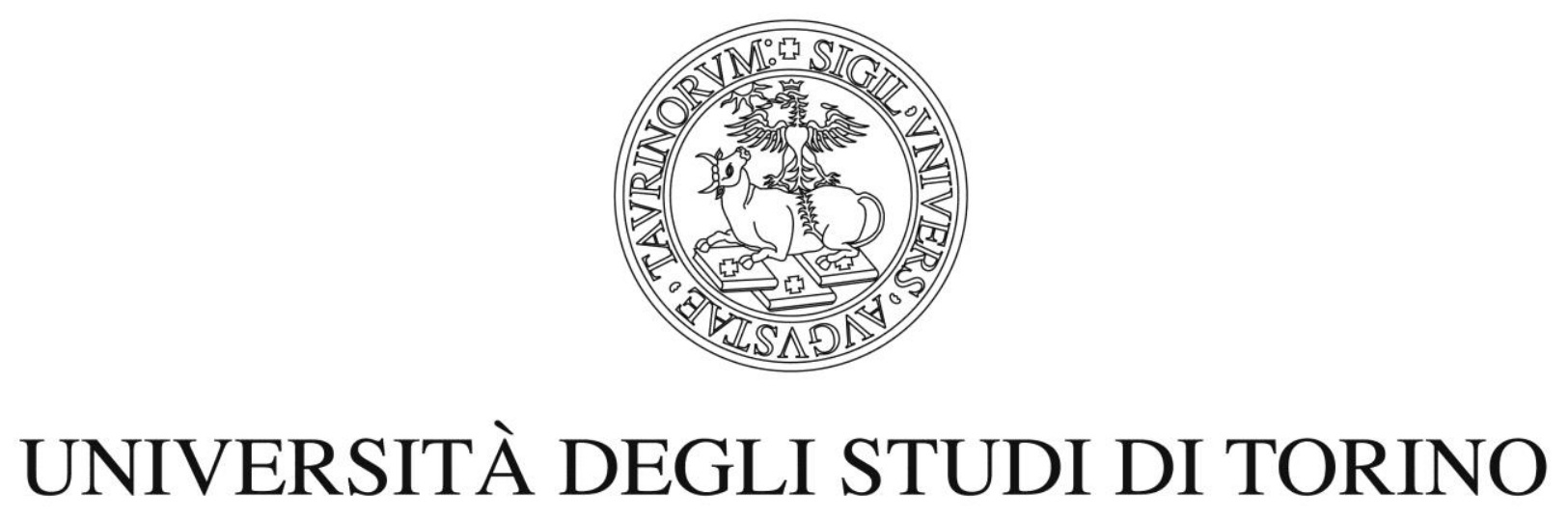

This is the accepted version of the following article: [CHIABRANDO, V. and GIACALONE, G. (2012), EFFECT OF ANTIBROWNING AGENTS ON COLOR AND RELATED ENZYMES IN FRESH-CUT APPLES DURING COLD STORAGE. Journal of Food Processing and Preservation, 36: 133-140], which has been published in final form at [http://onlinelibrary.wiley.com/doi/10.1111/j.1745-4549.2011.00561.x/full] 


\title{
EFFECT OF ANTIBROWNING AGENTS ON COLOR AND RELATED ENZYMES IN FRESH-CUT APPLES DURING COLD STORAGE
}

\author{
V. CHIABRANDO ${ }^{1}$ and G. GIACALONE \\ Department of Arboriculture, Turin University, Via L. da Vinci 44, 10095 Grugliasco (TO), Italy \\ ${ }^{1}$ Corresponding author. Tel +390116708938. Fax +390116708658, valentina.chiabrando@unito.it
}

\begin{abstract}
Treatments to inhibit browning of fresh-cut apples were investigated. The color $\left(L^{*}\right)$, the browning potential and polyphenol oxidase (PPO) activity of fresh-cut apples (Golden Delicious, Scarlet Spur and Granny Smith) were evaluated throughout cold storage. Antibrowning agents (citric and ascorbic acid) and calcium chloride resulted in a reduction of browning and deterioration of freshcut apples stored at $4{ }^{\circ} \mathrm{C}$ for 5 days under normal atmospheric conditions. During storage PPO activity increase and was inhibited by the use of citric and ascorbic acids. These antibrowning agents helped to maintaining the color of fresh-cut apples during storage. On the contrary, the use of 1-mcp was not effective to prevent the color deterioration of the apple slices from the first day of cold storage.
\end{abstract}

Keywords: antibrowning; apple slices; fresh-cut; polyphenoloxidase; enzymatic browning

\section{Practical Applications}

Ready-to-eat fruit and vegetable market has rapidly grown in recent years due to the health benefits associated with these foods because of busy lifestyles, increasing purchasing power, and increasingly health-conscious consumers. Nevertheless, because the tissular integrity of fruits is more easily altered during processing, ready-to-use commodities are more perishable than the original materials to browning surface. The use of organic acids such as malic acid, as well as physicochemical quality stabilizing compounds on fresh-cut fruits and vegetable can benefit the fresh-cut products industry, since they can assure the safety and quality of these products. The data collected of this study demostrated that treatments included $1 \% \mathrm{w} / \mathrm{v}$ of citric acid $/ \mathrm{CaCl}_{2}$ and $1 \%$ of ascorbic acid/ $\mathrm{CaCl}_{2}$ were effective inihibitors of browning surface. For practical purposes the results obtained, we recommend the use of ascorbic acid and citric acid to maintain quality of freshcut apples.

\section{INTRODUCTION}

Minimal processing has been defined as a combination of procedures, such as washing, sorting, trimming, peeling, and slicing or chopping, that do not affect the fresh-like quality of the food. Ready-to-eat fruits and vegetable market has rapidly grown in recent years due to the health benefits associated with these foods because of busy lifestyles, increasing purchasing power, and increasingly health-conscious consumers. Nevertheless, because the tissular integrity of fruits is more easily altered during processing, ready-to-use commodities are more perishable than the original materials. Deterioration of the fruit after minimal processing resulting from wound induced biochemical and physiological changes associated with water loss, respiration, and cut-surface browning has been accompanied by microbiological spoilage (Kader 2002).

Minimally processed apples have shorter shelf-life than the whole counterparts because they are more sensitive to enzymatic browning and tissue softening. these damages are stimulated by wounding of the tissue. Enzymatic browning of apples is caused by the action of polyphenoloxidase (PPO), which catalyses oxidation of phenolic compounds to the corresponding o-quinone in wounded tissues (Gacche et al. 2006). Color changes in fresh-cut fruit have been extensively reported (Eissa et al. 2006; Ilyidogan and Bayindirli, 2004; Lozano-de-Gonzalez et al. 1993) and most of the time browning has been considered the limiting factor of the shelf-life of minimally processed fruit. 
A range of treatments have been applied to extend the shelf life of fresh-cut apples including use of natural browning inhibitors (Buta et al. 1999; Luo and Barbosa-Canovas 1996; Rojas-Grau et al. 2006), salt and chemical treatments (Aguayo et al. 2010; Arias et al. 2008; Cocci et al., 2006; Gil et al. 1998; Varela et al. 2007; Zuo and Lee 2004), edible coating agents and reduced oxygen atmospheres (Perez-Gago et al. 2006; Rocculi et al. 2004; Rojas-Graï et al. 2007; Soliva-Fortuny et al. 2001). A key approach used to avoid browning in apples has been the use of reducing agents, often with the addition of calcium chloride, in combination with modified atmospheres and low temperature storage (Luo et al. 2006). Calcium salts, particularly $\mathrm{CaCl}_{2}$, are used as firming agents in a wide variety of whole, peeled, and fresh-cut fruits (Garcia and Barrett 2002; Luna-Guzman and Barret 2000).

Ethylene has an undesirable effect on the quality of fresh-cut fruit. 1-Methylcyclopropene (1-mcp) prevents ethylene effects in a broad range of fruit, vegetables and floriculture crops. For this reason 1-mcp is a good treatment for fresh-cut fruits. 1-mcp can be applied: immediately after harvest (Aguayo et al. 2006; Mao et al. 2007), just before fresh-cut processing or at both steps (Calderón-López et al. 2005; Vilas-Boas and Kader 2006). However, treatment of intact fruit with 1 -mcp before fresh-cut processing is much easier and more convenient than after processing. Moreover, the increase in ethylene production promoted by peeling and slicing can be prevented by the previous use of 1-mcp.

In Italy, fresh-cut fruit is usually treated only with ascorbic acid. For this reason the aims of this work were to evaluate the influence of different antibrowning treatments (no normally used) on the color changes and on the PPO activity that occurred in minimally processed apples during storage.

\section{MATERIALS AND METHODS Fruit processing}

The apples (Golden Delicious, Granny Smith and Scarlet Spur) were harvested at commercial maturity, and stored at $4^{\circ} \mathrm{C}$ before processing. Four kinds of samples were compared during the 5 days cold storage period:

1. apple slices treated with $1 \mu 11^{-1} 1$-mcp before peeling

2. apple slices dipped in ascorbic acid (1\%, w/v) and calcium chloride (1\%, w/v) (SigmaAldrich Co., Steinhein, Germany)

3. apple slices dipped in citric acid $(1 \%, \mathrm{w} / \mathrm{v})$ and calcium chloride $(1 \%, \mathrm{w} / \mathrm{v})$ (SigmaAldrich Co., Steinhein, Germany)

4. untreated apple slices

SmartFresh ${ }^{\mathrm{SM}}$ (1-mcp 0.14\%) was supplied by AgroFresh Inc. as a powder. After addition of distilled water it releases the active ingredient as gas, according to the manufacturer's instructions.

The fruits were peeled, cored and cut into 5-mm-thick slices using a hand-operated apple corer and slicer. Apple slices were dipped for $2 \mathrm{~min}$ in the different solutions in a product/solution ratio of 1:2 in according by previous works (Cocci et al. 2006; Soliva-Fortuny et al. 2001; SolivaFortuny et al. 2005). The sample number 1 and the control samples were processed in the same way but apple slices were dipped in water. The excess of solution was then blotted off, and 30 slices were randomly selected and packaged in polypropylene plastic bags (UNIMEC packaging systems). The packages were completely sealed and were stored at $4^{\circ} \mathrm{C}$ in darkness.

\section{Color measurement}

Color values of the cut apple surface were directly measured with a colormeter (Minolta ChromaMeterModel CR-400,Minolta, Tokyo, Japan). The results were expressed as CIELAB $\left(\mathrm{L}^{*} \mathrm{a}^{*} \mathrm{~b}^{*}\right)$ color space. $\mathrm{L}^{*}$ defines the lightness and $\mathrm{a}^{*}$ and $\mathrm{b}^{*}$ define the redgreenness and blueyellowness, respectively. The instrument was calibrated using a standard white reflector plate. Fifteen slices per treatment were measured. Three readings were made in each replicate by changing the position of the apple pieces. 


\section{Browning potential}

Browning potential was determined according to the method of Arias et al. (2008) in Golden Delicious and Granny Smith. The extract was obtained as followed: apple slices (25g) from each treatment were homogenized with an Ultra-Turrax homogenizer (IKAs WERKE, Germany), the homogenates were centrifuged (Centrifuge AVANTITM J-25, Beckman Instruments Inc., Fullerton, Calif., U.S.A.) at $4000 \mathrm{rpm}$ for $10 \mathrm{~min}$ and the supernatant was filtered through Whatman 4 filter paper (Whatman Intl., U.K.). The absorbance of the clear juice was then measured spectrophotometrically (Beckman $\mathrm{Du}^{\circledR} 530$ ) at $440 \mathrm{~nm}$ to determine potential browning. This measurement was replicated three times.

\section{Determination of PPO activity}

Enzyme extraction. A portion of $50 \mathrm{~g}$ of apple slices was mixed with a buffer solution (1:1) at $\mathrm{pH}=6.5$ containing $1 \mathrm{M} \mathrm{NaCl}$ (Sigma-Aldrich Chemie, Steinheim, Germany) and 5\% polyvinylpolypyrrolidone (Sigma-Aldrich Chemie, Steinheim, Germany). The mixture was blended and homogenized using an Ultra Turrax T25 (IKAs WERKE, Germany). The homogenate was centrifuged at $12500 \mathrm{rpm}$ for $30 \mathrm{~min}$ at $4^{\circ} \mathrm{C}$ (Centrifuge AVANTITM J-25, Beckman Instruments Inc., Fullerton, Calif., U.S.A.). The supernatant was collected and filtered through Whatman 1 paper (Whatman Intl., U.K.), and the resulting solution constituted the enzymatic extract, which was used for enzyme activity determination.

PPO activity measurement. Polyphenoloxidase activity was determined according to the method of Soliva-Fortuny et al. (2002) in Golden Delicious and Granny Smith. Enzyme activity was assayed spectrophotometrically by adding $3 \mathrm{~mL}$ of $0.05 \mathrm{M}$ catechol (Sigma-Aldrich Chemie, Steinheim, Germany) and $75 \mu \mathrm{L}$ of extract to a $4.5 \mathrm{~mL}$ quartz cuvette of $1 \mathrm{~cm}$ path length. The changes in absorbance at $400 \mathrm{~nm}$ were recorded every $5 \mathrm{~s}$ up to $3 \mathrm{~min}$ from the time the enzyme extract was added using a Beckman $\mathrm{Du}^{\circledR} 530$ spectrophotometer. One unit of PPO activity was defined as a change in absorbance of 0.001 per min and $\mathrm{mL}$ of enzymatic extract immediately after extract addition. The initial reaction rate was estimated from the linear portion of the plotted curve. All determinations were performed in triplicate.

\section{Statistical analysis}

Data were analyzed by analysis of variance using statistical procedures of the STATISTICA ver. 6.0 (Statsoft Inc., Tulsa, OK, USA). The sources of variance being anti-browning treatments. Tukey's test HSP (honestly significant differences) was used to determine significant differences among treatment means. Means values were considered significantly different at $\mathrm{P} \leq 0.05$.

\section{RESULTS AND DISCUSSION}

\section{Golden Delicious}

Browing was evaluated throughout a period of 5 days using colorimetric measurements. Many authors describe browning using both $\mathrm{L}^{*}$ value and $\mathrm{a}^{*}$ value as a good indicator of darkening of the sample and resulting from oxidative browning reactions or from increasing pigment concentrations (Arias et al. 2008; Iyidogan and Bayindirli 2004, Mchugh and Senesi 2000; RojasGrau et al. 2006; Sapers and Douglas 1987). Lightness of fresh-cut Golden Delicious apples not treated (control) decrease from 78.4 to 71.4 during 5 days of cold storage, while $\mathrm{L}^{*}$ values of freshcut slices treated with antibrowning agents were maintained constant (free of darkening) during all storage time. A same reduction was also reported by Soliva-Fortuny et al. (2001) in Golden Delicious apple and by Raybaudi-Massilia et al. (2007) in Fuji apple.

The treatment of Golden Delicious apple slides with the acidic formulations had a significant effect $(\mathrm{P} \leq 0.05)$ in inhibiting browning during storage at $4{ }^{\circ} \mathrm{C}$ contrary to the treatment with 1-mcp (Figure 1). This was based on the higher decrease in $\mathrm{L}^{*}$ value, indicative of browning and a less color maintenance, with high $\Delta \mathrm{E}^{*}$ values (Table 2). After 5 days, the 1-mcp treated 
samples showed severe browning and were no lighter than water-dipped control while samples treated with citric acid/ $\mathrm{CaCl}_{2}$ and ascorbic acid/ $\mathrm{CaCl}_{2}$ showed only slight browning (Figure 1).

Figure 2 shows data corresponding to the browning potential of the control and treated samples. Samples treated with acidic browning inhibitors had the lowest browning potential throughout the whole storage time. This reduction was significant at each data point (Figure 2), in according whith previous reserch (Cocci et al. 2005).

After the 5rd day of storage, the lowest browning potential was observed for ascorbic acid/ $\mathrm{CaCl}_{2}$ apple slices, the higher for 1-mcp apple slices (Figure 2). Ascorbic acid has been widely used as antibrowning agents for processing fruits and vegetables (Buta et al. 1999; Cocci et al. 2006; Luo et al. 1996; Tortoe et al. 2007) because it prevents enzymatic browning by reducing the quinone products to their original polyphenol compounds.

Many authors describde the succes of antioxidant treatments by evaluating the degree of inihibition to browing using the measurement of browning potential (Arias et al. 2008; Eissa et al. 2006).

The degree of inhibition based on browning potential was calculated using the equations of Iyidogan \& Bayindirh (2004) from BP values of the anti-browning agent added samples and the corresponding controls as follows:

\section{Degree of inhibition $=(\Delta \mathrm{BP}$ control $-\Delta \mathrm{BPtreatment}) / \Delta \mathrm{BP}$ control}

The results are shown in Table 1. The higher inhibition degree was found for citric $\mathrm{acid} / \mathrm{CaCl}_{2}$ treatment. Although ascorbic acid is a usual antibrowning agent, this inhibitor had not an effect on the color of different apple cultivars (Luo and Barbosa-Canovas 1997; Roja-Grau 2006) and its effectiveness in the degree of inhibition is lower than citric acid.

PPO activity of fresh-cut Golden Delicious apples treated with antibrowning agent increased from the early days after processing (Figure 3). The increase in PPO activity might be due to the activation of soluble tyrosinase forms existing in a latent state, which can be activated during storage by several factors (Kahn 1977). In this study we noted that the PPO activity was significantly different $(\mathrm{P} \leq 0.05)$ depending on the type of treatment used after 3 and 5 days of storage. After the 3rd day of storage, the highest PPO activity was observed for control apple slices. All of the chemical treatments resulted in a lower PPO activity than the control apple slices. The lowest relative PPO activity of apple slices was obtained in the citric acid/ $\mathrm{CaCl}_{2}$ treated slices. Citric acid treatment reduced the increase of PPO activity to $30 \%$ compared to control apple slices after 5 days of storage (Figure 3) and its inhibitory effect could be related to the phenolase $\mathrm{Cu}-$ chelating power (Tortoe et al. 2007).

\section{Granny Smith}

The color L* value of fresh-cut Granny Smith slices decreased with time in storage (Figure 4). During the 5 days of storage at $4^{\circ} \mathrm{C}$, fresh-cut apple treated with citric acid/ $/ \mathrm{CaCl}_{2}$ resulted in the best maintenance of $\mathrm{L}^{*}$ values followed by the ascorbic acid/ $\mathrm{CaCl}_{2}$ treatment (Fig. 4). Fresh-cut slices under these treatments presented the best visual appearance and fewer symptoms of browning. $\mathrm{L}^{*}$ values of these treatments were reduced slightly after 5 days of storage and were significantly different $(\mathrm{P} \leq 0.05)$ from the control and treated with 1-mcp slices.

By contrast, control and 1-mcp sample showed the lowest $\mathrm{L}^{*}$ value and a very high $\Delta \mathrm{E}^{*}$ values. Under this condicion of cut-surface browning, the consumer could distinguish between apple treated with acidic antibrowning and control slices. Kim et al. (1993) reported that a rapid decrease in $L^{*}$ values of fresh-cut apples can be due to enzymatic browning caused by tissue damage. The consequence is a enhanced contact between enzymes and substrates that led to a loss of quality of fresh-cut produce. Lozano-de-Gonzalez et al. (1993) suggest that the browning in apple slices could be attributed to the consumption of substrates by PPO. The lower the L* values, the higher the browning potential and the relative PPO activity (Figures 4-6). 
Figure 5 shows data corresponding to the browning potential of the control and treated samples. Samples treated with acidic browning inhibitors (ascorbic and citric acids) had the lowest browning potential throughout the whole storage time and were significantly different $(\mathrm{P} \leq 0.05)$ after 3 and 5 days of storage. Tha application of 1-mcp did not affect the browning potential of apple slices during storage.

The inhibition degrees are shown in Table 1. In according with the Golden Delious results slices treated with citric acid/ $\mathrm{CaCl}_{2}$ showed much higher inhibition degree. On the contrary, apple slices treated with 1-mcp showed the lowest inhibition degree.

PPO activity of fresch-cut Granny Smith apples treated with ascorbic acid, 1-mcp and nontreated slices increased from early days after processing (Figure 6). Luo and Barbosa-Canova (1997) indicated that ascorbic acid is consumed during antibrowning reactions, for this reason in this study we can see the increase in PPO activity of ascorbic acid/ $\mathrm{CaCl}_{2}$ apple slices during storage. As shown in figure 6, the lowest relative PPO activity of apple slices was obtained with the use of citric acid/ $/ \mathrm{CaCl}_{2}$. In contrast, the significant $(\mathrm{P} \leq 0.05)$ higher relative PPO activity was observed in control apple slices.

\section{Scarlet Spur}

Color changes of fresh-cut Scarlet Spur slices was determined by changes in lightness (L*) (Figures 7). The $\mathrm{L}^{*}$ value decreased (darkening increased) with time in all the samples. An ANOVA test showed significant differences $(\mathrm{p} \leq 0.05)$ after 1 day of storage between apple slices treated with antibrownin agent (ascorbic acid) and control and 1-mcp treated slices (Figures 7) suggesting a fast darkening from the early hours of storage (Figures 7 ). The change in the L* value was due to the slight browning on the surface of the slices probabily due to the consumption of substrates by PPO (Lozano de Gonzales et al. 1993).

Fresh-cut Scarlet Spur control apples and treated with 1-mcp showed a lightness decrease from 78.4 to 71 during 5 days of cold storage, while $L^{*}$ values of treated fresh-cut apples with antibrowning agent were maintained constant during all storage time without any significant decrease (from 78.4 to 74.5). Application of 1-mcp before processing did not affect the $\mathrm{L}^{*}$ value in comparison with control slices, in according with Vilas-Boas and Kader (2007) in fresh-cut kiwifruit and mango.

\section{CONCLUSION}

In the present study the influence of different antibrowning treatments on color changes and on the PPO activity that occurred in minimally processed apples during storage had been examined. The collected data demostrated that $1 \% \mathrm{w} / \mathrm{v}$ of citric acid $/ \mathrm{CaCl}_{2}$ and $1 \%$ of ascorbic acid/ $\mathrm{CaCl}_{2}$ treatments were effective inihibitors of PPO. The results obteined with $\mathrm{L}^{*}$ values corroborated the positive effect of citric and ascorbic acids in the control of the enzymatic browning in Golden Delicious, Granny Smith and Scarlet Spur apples slices. However, in general, the rate of deterioration of the slices was not affected by 1-mcp treatment. Among the apples cultivar studied in this research, the most suitable variety for minimal processing was Golden Delicious apple for its low susceptibility to superficial browning (low browning potential values).

\section{REFERENCES}

AGUAYO, E., JANSASITHORN R.. and KADER A.A. 2006. Combined effects of 1methylcyclopropene, calcium chloride dip, and/or atmospheric modification on quality changes in fresh-cut strawberries. Post. Biol.Technol. 40, 269-278.

AGUAYO, E., REQUEJO-JACKMAN, C., STANLEY, R. and WOOLF, A. 2010. Effects of calcium ascorbate treatments and storage atmosphere on antioxidant activity and quality of fresh-cut apple slices. Post. Biol.Technol. 57, 52-60. 
ARIAS, E., GONZALEZ, J., LOPEZ-BUESA, P. and ORIA, R. 2008. Optimization of processing of fresh-cut pear. J. Sci. Food Agric. 88, 1755-1763.

BOURNE, M.C. 1980. Textural evaluation of horticultural crops. HortSci. 15, 51-56.

BUTA, J.G., MOLINE H.E., SPAULDING D.W. and WANG C.Y. 1999. Extending storage life of fresh-cut apples using natural products and their derivatives. J.Agric.Food Chem. 47, 456461.

CALDERÓN-LÓPEZ, B., BARTSCH, J.A., LEE, C.H.. and WATKINS, C.H.. 2005. Cultivar effects on quality of fresh cut apple slices from 1-methylcyclopropene (1-MCP) treated apple fruit. J. Food Sci. 70, 221-227.

COCCI, E., ROCCOLI, P., ROMANI, S. and DALLA ROSA, M. 2006. Changes in nutritional properties of minimally processed apples during storage. Post. Biol.Technol. 39, 265-271.

EISSA, H.A., HODA, H.M., FADEL, G.E., IBRAHIM, I.M., HASSAN, A. and ELRASHID, A.A. 2006. Thiol containing compounds as controlling agents of enzymatic browning in some apple products. Food Res. Inter. 39, 855-863.

KADER, A. 2002. Quality parameters of fresh-cut fruit and vegetable products. In: Lamikanra, O. (Ed.), Fresh-cut Fruits and Vegetables. Science, Technology, and Market. CRC Press, Boca Raton, FL, 11-19.

KAHN, V. 1977. Latency properties of polyphenol oxidase in two avocado cultivars differing in their rate of browning. J. Sci. Food Agric. 28, 233-29.

KIM, D.M., SMITH, N.L and LEE, C.Y. 1993. Quality of Minimally Processed Apple Slices from Selected Cultivars. J. Food Sci. 58, 1115-1117.

IIYIDOGAN, N.F. and BAYINDIRLI A.. 2004. Effect of L-cysteine, kojic acid and 4hexylresorcinol combination on inhibition of enzymatic browning in Amasya apple juice. $\mathrm{J}$. Food Eng. 62, 299-304.

LOZANO-DE-GONZALEZ, P., BARRET, D.M., WOLSTAD, R.E., and DURST R.W. 1993. Enzymatic browning inhibited in fresh and dried apple rings by pineapple juice. J. Food Sci. 58, 399-345.

LUO, Y., and BARBOSA-CANOVAS, G.V. 1996. Preservation of apple slices using ascorbic acid and 4hexylresorcinol. Food Sci. Technol. Int. 2, 315-321.

LUO, Y., and BARBOSA-CANOVAS, G.V. 1997. Enzymatic browning and its inhibition in new apple cultivars slices using 4-hexylresorcinol in combination with ascorbic acid. Food Sci. Technol. Int. 3, 195-201.

MAO, L., and FEI, G. 2007. Application of 1-methylciclopropene prior to cutting reduces wound responses and maintains quality in cut kiwifruit. J. Food Eng. 78, 361-365.

MCHUGH, T.H., and SENESI, E. 2000. Apple Wraps: A Novel Method to Improve the Quality and Extend the Shelf Life of Fresh-cut Apples. J. Food Sci. 65, 336-342.

PEREZ-GAGO, M.B., SERRA M. and DEL RIO, M.A. 2006. Color change of fresh-cut apples coated with hey protein concentrate-based edible coatings. Post. Biol.Technol. 39, 84-92.

RAYBAUDI-MASSILIA, R.M., MOSQUEDA-MELGAR, J., SOBRINO-L'OPEZ, A., SOLIVAFORTUNY, R. and MARTIN-BELLOSO O. 2007. Shelf-life extension of fresh-cut "Fuji" apples at different ripeness stages using natural substances. Post. Biol.Technol. 45, 265-275.

ROCHA, A.M.C.N. and DE MORAIS, A.M.M.B. 2005. Polyphenoloxidase activity of minimally processed "Jonagored" apples (Malus Domestica). J. Food Proc.Preserv. 29, 8-19.

ROJAS-GRAU, M.A., SOBRINO-LOPEZ, A., TAPIA, M.S. and MARTÍN-BELLOSO, O. 2006. Browning Inhibition in Fresh-cut 'Fuji' Apple Slices by Natural Antibrowning Agents. J. Food Sci. 71, 125-129.

ROJAS-GRAÜ, M.A., RAYBAUDI-MASSILIA, R.M., SOLIVA-FORTUNY, R.C., AVENABUSTILlOS, R.J., MCHUGH, T.H. and MARTÍN-BELLOSO, O. 2007. Apple pureealginate edible coating as carrier of antimicrobial agents to prolong shelf-life of freshcutapples Post. Biol.Technol. 45, 254-264. 
ROLLE, R.S. and CHISM, G.W. 1987. Physiological consequences of minimally processed fruits and vegetables. J. Food Qual. 10, 157-177.

SAPERS, G.M. and DOUGLAS, F.W. 1987. Measurement of enzymatic browning at cut surfaces and in juice of raw apple and pear fruits. J. Food Sci. 52, 1258-1262.

SOLIVA-FORTUNY, R.C., GRIGELMO-MIGUEL， N., ODRIOZOLA-SERRANO, I., GORINSTEIN, S. and MARTIN-BELLOSO, O. 2001. Browning Evaluation of Ready-toEat apples as affected by modified atmosphere packaging. J. Agric. Food Chem. 49, 36853690.

SOLIVA-FORTUNY, R.C., RICART-COLL, M. and MARTIN-BELLOSO O. 2005. Sensory quality and internal atmosphere of fresh-cut Golden Delicious apples. Inter. J. Food Sci.Technol. 40, 369-375.

TORTOE, C., ORCHARD, J. and BEEZER, A. 2007. Prevention of enzymatic browning of apple cylinders using different solutions. Inter. J. Food Sci.Technol. 42, 1475-1481.

VILAS-BOAS, E. and KADER, A. 2006. Effect of 1-MCP on softening of fresh-cut kiwifruit, mango and persimmon slices. Post. Biol.Technol. 43, 238-244. 
TABLE 1. DEGREE OF INHIBITION OBSERVED FOR GOLDEN DELICIOUS AND GRANNY SMITH APPLE SLICES

\begin{tabular}{lcccc}
\hline & \multicolumn{2}{c}{ Golden Delicious } & \multicolumn{2}{c}{ Granny Smith } \\
\hline & $\Delta \mathrm{BP}$ & $\begin{array}{c}\text { Degree of } \\
\text { inhibition }\end{array}$ & $\Delta \mathrm{BP}$ & $\begin{array}{l}\text { Degree of } \\
\text { inhibition }\end{array}$ \\
\hline control & 0.22 & & 0.4 & \\
1-mcp & 0.02 & 0.9 & 0.18 & 0.55 \\
ascorbic acid/CaCl2 & -0.4 & 2.81 & -0.17 & 1.42 \\
citric acid/CaCl2 & -1.05 & 5.77 & -0.32 & 1.77 \\
\hline
\end{tabular}

TABLE 2. COLOUR DIFFERENCE ( $\triangle \mathrm{E}^{*}$ ) OF GOLDEN DELICIOUS, GRANNY SMITH APPLE SLICES AND SCARLET SPUR APPLES

\begin{tabular}{llllllll}
\hline days at $4{ }^{\circ} \mathrm{C}$ & & 0 & 1 & 2 & 3 & 4 & 5 \\
\hline Golden Delicious & control & 0 & 4.31 & 6.41 & 5.95 & 7.08 & 6.08 \\
& 1 -mcp & 0 & 6.48 & 8.98 & 7.68 & 7.61 & 6.05 \\
& ascorbic acid/ $\mathrm{CaCl}_{2}$ & 0 & 2.75 & 2.78 & 4.04 & 5.08 & 3.47 \\
& citric acid/ $/ \mathrm{CaCl}_{2}$ & 0 & 0.25 & 0.93 & 1.29 & 2.83 & 2.71 \\
\hline Granny Smith & control & 0 & 9.94 & 9.74 & 9.57 & 10.14 & 11.93 \\
& 1 -mcp & 0 & 9.24 & 8.54 & 8.96 & 8.73 & 10.05 \\
& ascorbic acid/ $/ \mathrm{CaCl}_{2}$ & 0 & 3.25 & 1.97 & 1.18 & 3.89 & 2.98 \\
& citric acid/CaCl & 0 & 2.40 & 0.04 & 2.08 & 0.53 & 1.34 \\
\hline Scarlet Spur & control & 0 & 7.64 & 8.45 & 9.42 & 8.37 & 6.33 \\
& 1-mcp & 0 & 8.68 & 8.97 & 10.47 & 9.23 & 7.33 \\
& ascorbic acid/ $/ \mathrm{CaCl}_{2}$ & 0 & 0.13 & 4.72 & 7.36 & 3.51 & 3.83 \\
\hline
\end{tabular}




\section{Figures}

FIGURE 1. EFFECT OF ANTI-BROWNING TREATMENTS ON L* VALUES OF GOLDEN DELICIOUS SLICES DURING COLD STORAGE AT $4^{\circ} \mathrm{C}$

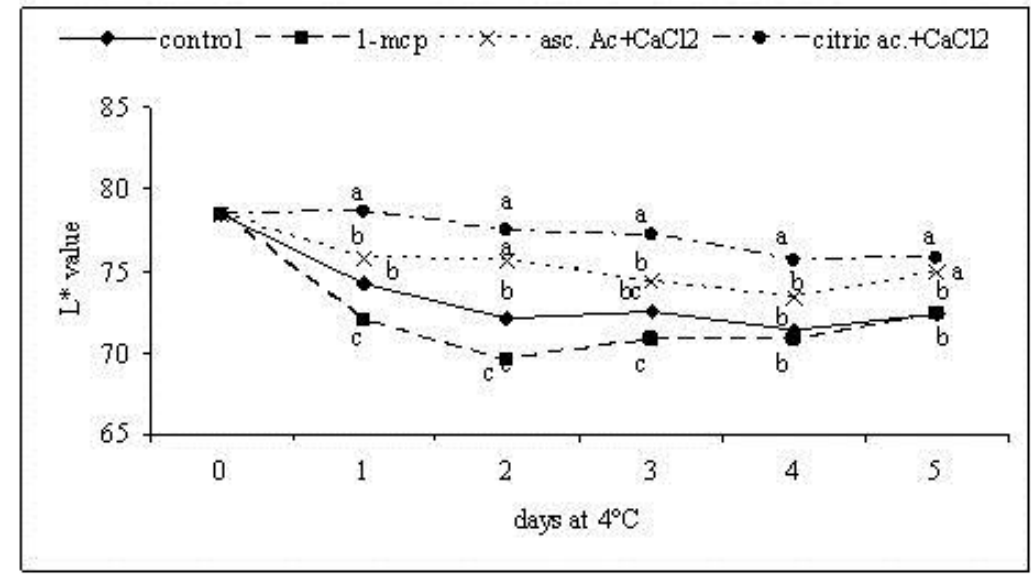

Different letters are signific antly different $(\mathrm{P}=0.05)$ for trestment over time. 
FIGURE 2. EFFECT OF ANTIBROWNING TRETMENTS ON POTENTIAL BROWNING VALUE OF GOLDEN DELICIOUS SLICES TREATED WITH ANTIBROWNING AGENTS, DURING STORAGE AT $4^{\circ} \mathrm{C}$

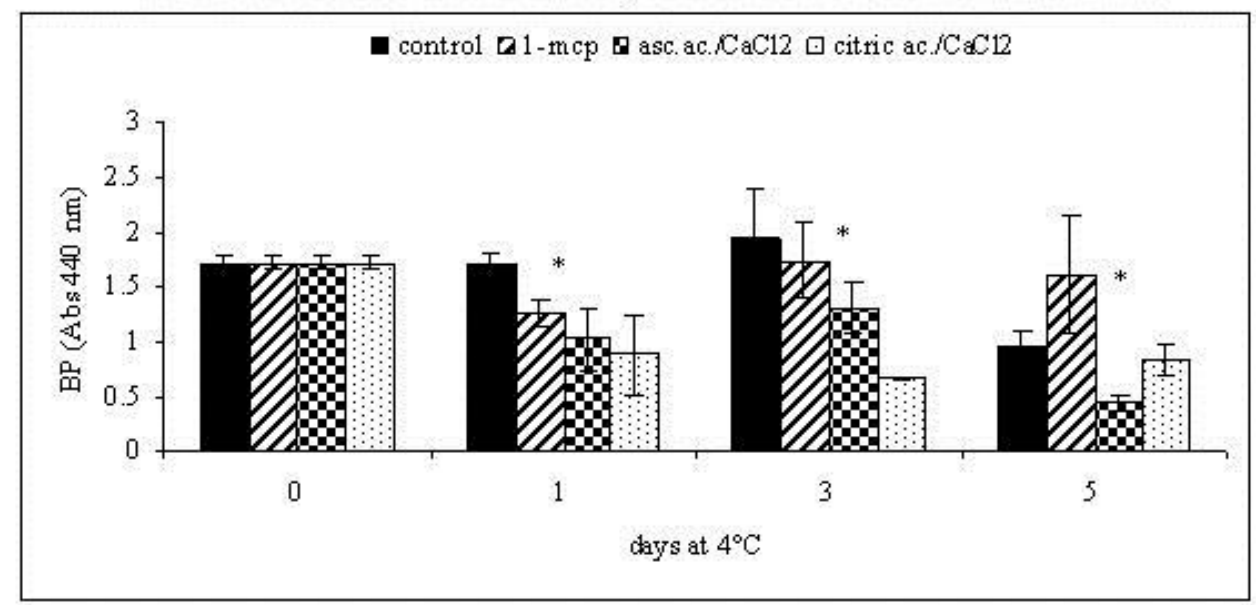

Vabues are means of three detemminations $\pm S D$

HSignificart difference ( $\mathrm{P}<0.05$ ) of trestment over time. 
FIGURE 3. EVOLUTION OF RELATIVE POLYPHENOL OXIDASE (PPO) ACTIVITY ON GOLDEN DELICIOUS SLICES TREATED WITH ANTIBROWNIYG AGENTS, DURING STORAGE $A T 4^{\circ} \mathrm{C}$

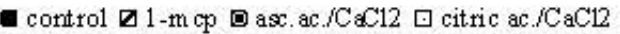

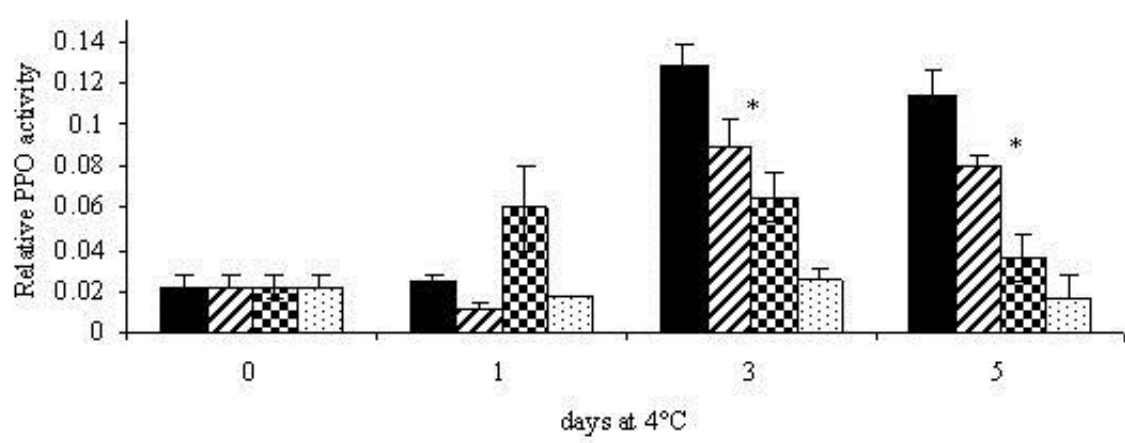

Vahues are means of three deteminations $\pm S D$

HSignificart difference $(\mathrm{P}<0.05)$ of trestment over time.

FIGURE 4 EFFECT OF ANTI-BROWNING TREATMENTS ON L* VALUES OF GRANNY SMITH SLICES DURING COLD STORAGE AT $4^{\circ} \mathrm{C}$

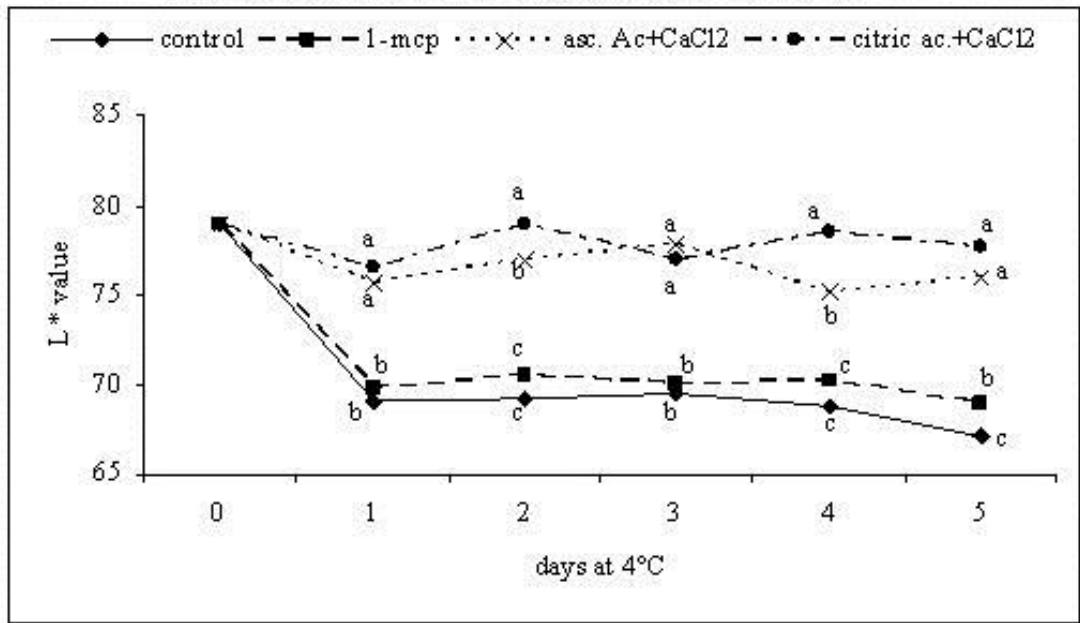

WDifferent letters are signific antly different $(\mathrm{P}<0.05$ ) for trestment over time 
FIGURE S. EFFECT OF ANTIBROWNING TRETMENTS ON POTENTIAL BROWNING VALUE OF GRANNY SMITH SLICES TREATED WITH ANTIBROWNING AGENTS, DURING STORAGE AT $4^{\circ} \mathrm{C}$

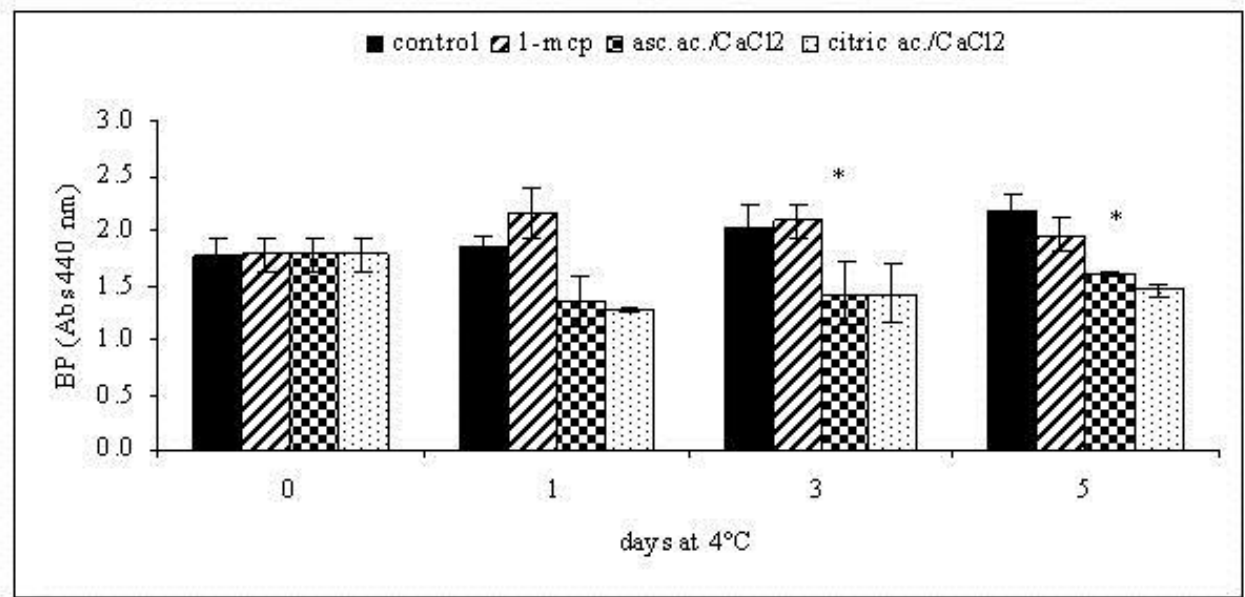

Vabues are means of three detemminations $\pm S D$

"Significant difference $(\mathrm{P}<0.05)$ of treatment over time

FIGURE 6. EVOLUTION OF RELATIVE POLYPHENOL OXIDASE (PPO) ACTIVITY ON GRANNY SMITH SLICES TREATED WITH ANTIBROWNING AGENTS, DURING STORAGE AT $4^{\circ} \mathrm{C}$

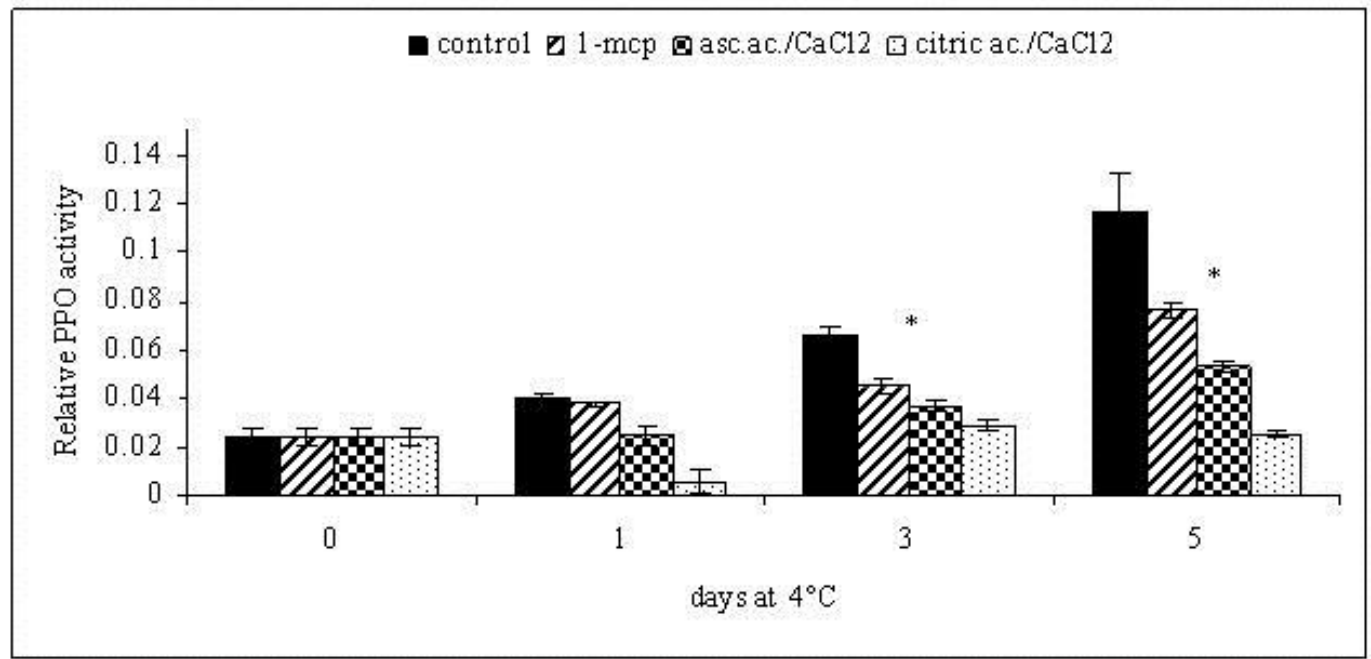

Wahues are means of three deteminations \pm SD

"Significant difference $(\mathrm{P}<0.05)$ of treatment over time 
FIGURE 7. EFFECT OF ANTI-BROWNING TREATMENTS ON L* VALUES OF SCARLET SPUR SLICES DURING COLD STORAGE AT $4^{\circ} \mathrm{C}$

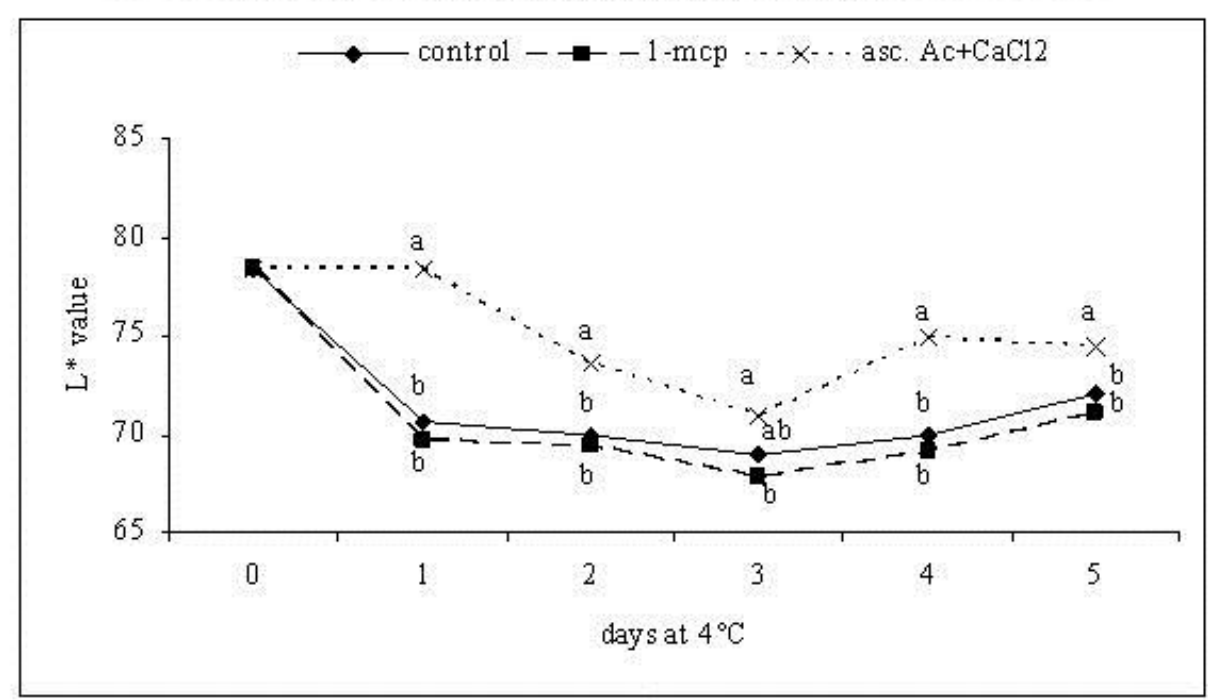

MDifferent letters are signific antly different $(\mathrm{P}<0.05)$ for treatment over time 